\title{
THE DISTRIBUTION AND ACCUMULATION OF CHROMIUM IN THE WATER, SEDIMENT AND MACROPHYTES OF SKADAR LAKE
}

\author{
Vlatko Kastratović $^{1 *}$, Željko Jaćimović², Miljan Bigović ${ }^{1}$, \\ Dijana Đurović ${ }^{3}$, Slađana Krivokapić ${ }^{1}$ \\ ${ }^{1}$ Faculty of Natural Sciences and Mathematics, University of Montenegro, \\ Džordža Vašingtona bb, 81000 Podgorica, Montenegro, \\ ${ }^{2}$ Faculty of Metallurgy and Technology, University of Montenegro, Podgorica, Montenegro, \\ ${ }^{3}$ Institute of Public Health of Montenegro, Podgorica, Montenegro \\ *Corresponding author; E-mail: vlatkok@ac.me
}

(Received February 3, 2016)

\begin{abstract}
The aquatic macrophytes Phragmites australis (Cav.) Trin. ex Steud., Ceratophyllum demersum L., and Lemna minor $\mathrm{L}$. were used as bioindicator plant species in order to define contamination level by $\mathrm{Cr}$ in Skadar lake (Montenegro). Plants, water and sediments were tested for the content of $\mathrm{Cr}$ at six locations around Lake Skadar during four periods in 2011. The content of $\mathrm{Cr}$ in the examined sediment was in the range of $35.6-127 \mathrm{mg} / \mathrm{kg}$ dry weight. The largest proportion of detected $\mathrm{Cr}(50.6 \%)$ was associated with the oxidizable phase in the form of organic complexes. The concentration of $\mathrm{Cr}$ in the studied macrophytes declined in the following order: $C$. demersum $>P$. australis $>$ L. minor. The highest average content of $\mathrm{Cr}$ was detected in the leaf of $C$. demersum $(11.4 \mathrm{mg} / \mathrm{kg})$ in April.
\end{abstract}

Keywords: Lake Skadar, chromium, P. australis, C. demersum, L. minor

\section{INTRODUCTION}

It is known that metals are natural ingredients of fresh water ecosystems where they are found in relatively low concentrations (BABOVIĆ et al., 2010). The main sources of microelements, i.e. heavy metals in natural waters, are related to natural processes and anthropogenic impact. Their common property is that even at relatively low concentrations their effects are toxic and therefore they fall under the category of very dangerous environmental pollutants (KASTORI and MAKSIMOVIC, 2006).

The fact that heavy metals are present in the environment does not mean that they are available for adoption by living organisms or for incorporation by them. The determination of the total amount of heavy metals in the sediment is insufficient to assess their environmental impact on aquatic ecosystems. Some of the metals are incorporated into the crystal lattice of minerals or firmly attached to other substrates of sediment and thus does not represent a threat to biota. What is much more important is the information on the amount of bioavailable (mobile) metals that are only available to the living world in the lake. A simulation of the real situation in the lake environment that leads to the increased mobility of metals can be made by their extraction from sediment by using various means of extraction. 
Aquatic plants absorb metals from environment and concentrate them into their tissues. In this way, the metal entered into the trophic chain (OUTRIDGE and NOLLER, 1991; TREMP and KOHLER, 1995). According to KovACS et al., (1984) aquatic plants may accumulate considerable amounts of heavy metals in their tissues (perhaps 10-10 ${ }^{6}$ times higher than those in nearby environment).

In natural waters, $\mathrm{Cr}$ concentrations are low except in locations that are loaded by waste containing $\mathrm{Cr}$. The concentration of dissolved $\mathrm{Cr}$ in unpolluted lakes and rivers usually varies between 1 and $2 \mu \mathrm{g} / \mathrm{dm}^{3}$. Higher values ( 5 to $50 \mu \mathrm{g} / \mathrm{dm}^{3}$ ) are found in some large rivers that flow through industrial areas. This is usually related to the discharge of waste water from large industrial facilities (AGBABA et al., 2008). Due to the presence of anthropogenic sources of pollution, increases in the level of $\mathrm{Cr}$ in the sediment have been found. The enrichment of sediments is correlated with the influx of ash from different sources - the combustion of oil, coal and wood, noting that the filtration devices on chimneys significantly contributed to the reduction of $\mathrm{Cr}$ content in the sediments (VESELINOVIĆ et al., 1995). The solubility of $\mathrm{Cr}$ in the water present in the soil is less than other potentially toxic metals, thus explaining the low level of its adoption by the plants. The accumulation of $\mathrm{Cr}$ by plants can reduce growth, induce chlorosis in young leaves, reduce pigment content, alter enzymatic function, damage root cells and cause ultrastructural modifications to the chloroplast and cell membrane (Choudhury and PANDA, 2005). Chromium toxicity in plants depends on its valence state (OlIVEIRA, 2012). Chromium (VI) is toxic to plants and does not play any role in plant metabolism. Contrarily to $\mathrm{Cr}(\mathrm{VI}), \mathrm{Cr}(\mathrm{III})$ at low concentrations $\left(0.05-1 \mathrm{mg} / \mathrm{dm}^{3}\right)$ was found to promote growth and increase yield, but it is not considered essential to plants (PERALTAVIDEA et al., 2009; PAIVA et al., 2009). Chromium (III) is found to be less soluble in water and less toxic than $\mathrm{Cr}(\mathrm{VI})$ and is required in very low concentrations as an inorganic nutrient for some plants (SCHIAVON et al., 2008 ). The normal range of $\mathrm{Cr}$ in plants is $0.03-14 \mathrm{mg} / \mathrm{kg}$ (BOWEN, 1979) and the critical concentration is $15-30 \mathrm{mg} / \mathrm{kg}$ (KABATA-PENDIAS and PENDIAS, 1992).

The determination of metal content by sediment fractions, then the estimation of their bioavailability, the analysis of relevant ratios of metal content in the sediment, water and macrophytes and its distribution in different plant tissues, may all indicate the possible pathways of absorption, distribution and potential for bioaccumulation.

Our research aims to find the $\mathrm{Cr}$ content per fractions of sediments, and estimate bioavailability, including by analysing content ratios in the sediment, in water and macrophytes and plant tissue distibution, which can indicate possible absorption or distribution mechanisms and ability to bioaccumulate $\mathrm{Cr}$.

\section{MATERIALS AND METHODS}

The aquatic macrophytes used as indicator species in this study Phragmites australis (Cav.) Trin. ex Steud., Ceratophyllum demersum L., and Lemna minor L. were taken from six locations around Lake Skadar, Montenegro. The locations were: 1- Raduš, 2- right estuary of the Morača River, 3- estuary of the Morača River, 4- Plavnica, 5- Crni Žar and 6Rijeka Crnojevića (Figure 1). The samples were collected during four separate periods in 2011. The samples of $P$. australis and $C$. demersum were collected four times during 2011 at the six locations. The samples of L. minor were collected in two time periods, in August and October, from four locations. Samples of sediment and water were taken at the same time and from the same places as plant material. 


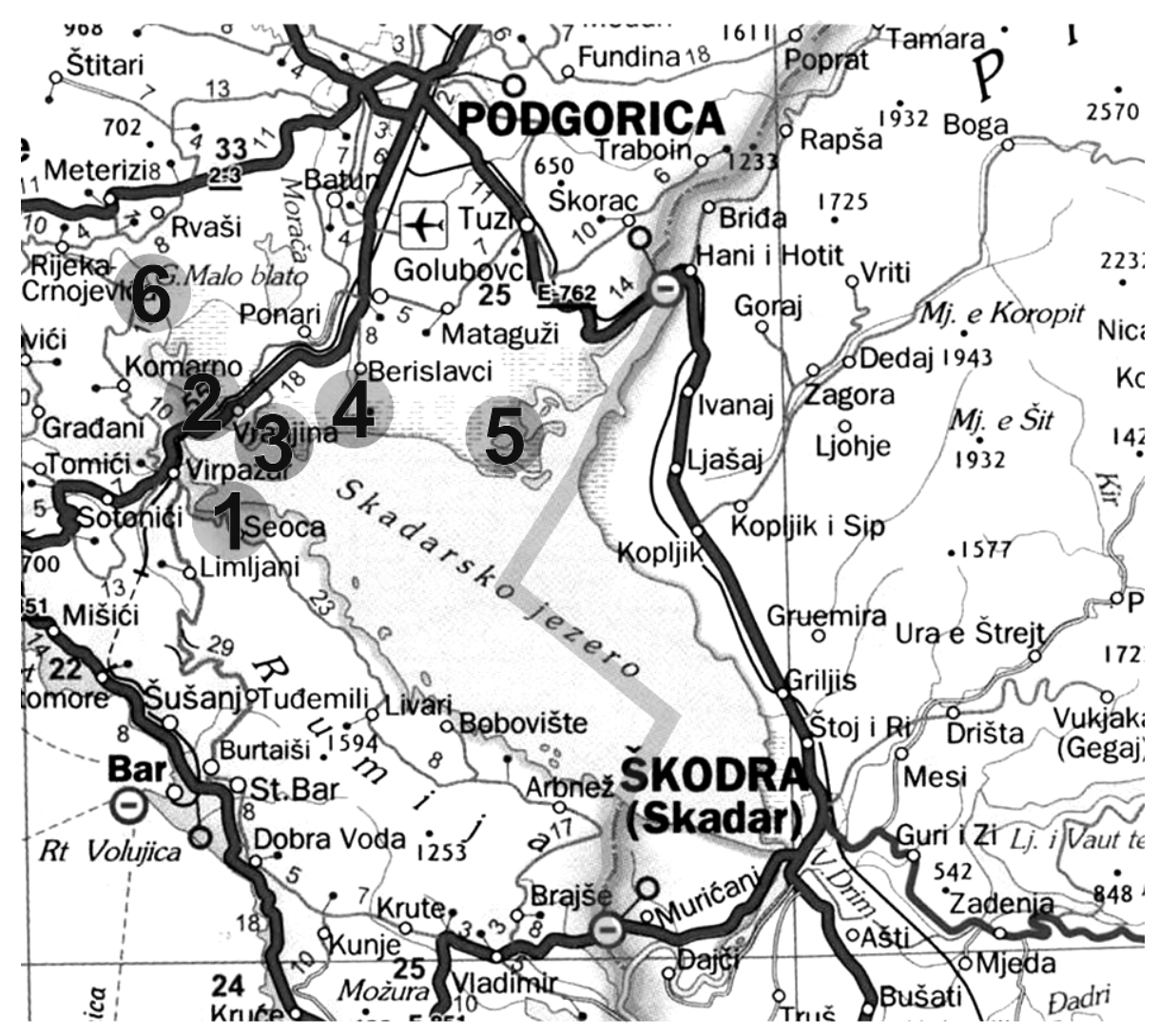

Figure 1. Location of the sampling stations around Lake Skadar

The plant material was separated in the laboratory into the root, stem and leaf of $P$. australis, the stem and leaf of $C$. demersum and the root and leaf of $L$. minor in order to determine bioaccumulation degree of each organ. The plant material then was dried at $75^{\circ} \mathrm{C}$ over a 48 hour period. The samples were ground to a fine powder and homogenized. The samples were mineralized to avoid the influence of the matrix. The prepared plant samples, approximately $0.5 \mathrm{~g}( \pm 0.0001 \mathrm{~g})$, were mineralized in a Milestone Microwave Ethos 1, with a mixture of $\mathrm{HNO}_{3}$ and $\mathrm{H}_{2} \mathrm{O}_{2}(3: 1)$.

Sediment samples, approximately $500 \mathrm{~g}$, were air dried and then dried at $75^{\circ} \mathrm{C}$ over 48 hours. The dried sediment samples were chopped in an agate mortar and sieved through a sieve $<1.5 \mathrm{~mm}$. The sediment samples, approximately $0.5 \mathrm{~g}( \pm 0.0001 \mathrm{~g})$, were mineralized with a mixture of $\mathrm{HCl}: \mathrm{HNO}_{3}(3: 1)$ in a microwave furnace, a Milestone Microwave Ethos 1 (USEPA, 2007). The water samples were filtered through a $0.45 \mu \mathrm{m}$ Millipore filter and stored in $1 \mathrm{~L}$ plastic bottles with the addition of $2 \mathrm{~mL}$ of $\mathrm{HNO}_{3}$.

In order to determine the distribution of the $\mathrm{Cr}$ in the sediment we applied a modified BCR (the Community Bureau of Reference of the European Union) sequential extraction procedure of the sample sediment (PUEYO et al., 2003).

Mobile forms of $\mathrm{Cr}$ were determined using five different extracting solutions: cationexchangeable $\left(\mathrm{NH}_{4} \mathrm{Cl}, \mathrm{CaCl}_{2}, \mathrm{CH}_{3} \mathrm{COONa}\right.$ ), organic acid (oxalic acid) and complexing reagent (EDTA).

Determining the concentration of $\mathrm{Cr}$ in the samples of water, sediments and plants was conducted by ICP-OES technique on a "Spectro Arcos" device.

The capacity of plants to absorb and accumulate metals from the growth media was evaluated by their bio-concentration factor $(\mathrm{BCF})$. The $\mathrm{BCF}$ was calculated as the ratio of the concentrations of metals in parts of the plant and the water: $\mathrm{BCF}=[\mathrm{Metal}]$ part of plant $/[\mathrm{Metal}]$ water (HAWKER and CONNELL, 1991). The ability of plants to transport metals from their roots to their shoot was assessed by translocation ability (TA). Translocation ability is calculated as 
the ratio of the concentrations of metals in a part of a plant and its root: $\mathrm{TA}=[\mathrm{Metal}]_{\mathrm{part}}$ of the plant $/[\text { Metal }]_{\text {root }}$, and for $C$. demersum as the ratio of metal concentrations in the leaf and the stem: $\mathrm{TA}=[\text { Metal }]_{\text {leaf }} /[\text { Metal }]_{\text {stem }}$ (DENG et al., 2004).

\section{RESULTS AND DISCUSSION}

Low $\mathrm{Cr}$ contents were recorded in the water. At four of the six sampled sites the content of $\mathrm{Cr}$ was below the detection limit of the instrument $\left(\mathrm{LOD}_{\mathrm{Cr}}=0.002 \mathrm{mg} / \mathrm{dm}^{3}\right)$. At the locations of Plavnica and Rijeka Crnojevića, there was no seasonal variation in Cr content and the readings amounted to 0.003 and $0.002 \mathrm{mg} / \mathrm{dm}^{3}$, respectively.

The concentration values of $\mathrm{Cr}$ in the sediments are given in Table 1. During the research period (April-October) there were no recorded statistically significant temporal variations in the concentration of metals in the sediment, but there were spatial variations. The highest concentrations of $\mathrm{Cr}$ were recorded in the sediment samples from Plavnica, and the lowest ones were recorded in the sediments from Raduša and Rijeka Crnojevića.

Table 1. Minimum - maximum and average concentrations \pm standard deviation (S.D.) ${ }^{*}$ of $\mathrm{Cr}$ in sediment $(\mathrm{mg} / \mathrm{kg})$

\begin{tabular}{ccccccc}
\hline Location & Raduš & $\begin{array}{c}\text { Right } \\
\text { mouth }\end{array}$ & $\begin{array}{c}\text { Left } \\
\text { mouth }\end{array}$ & Plavnica & Crni Žar & $\begin{array}{c}\text { Rijeka } \\
\text { Crnojevića }\end{array}$ \\
\hline \multirow{2}{*}{ Sediment } & $35.6-44.6$ & $73.1-76.3$ & $68.9-74.5$ & $117-127$ & $54.6-62.6$ & $40.4-45.5$ \\
& $40.7 \pm 3.93$ & $75.0 \pm 1.34$ & $71.2 \pm 2.38$ & $123 \pm 4.54$ & $57.9 \pm 3.46$ & $42.6 \pm 2.11$ \\
\hline \multicolumn{2}{c}{$\mathrm{n}=4$} & & & & &
\end{tabular}

The mean values of the concentrations of $\mathrm{Cr}(\mathrm{mg} / \mathrm{kg})$ as a result of the sequential extraction of sediments are shown in Table 2:

Table 2. Distribution of $\mathrm{Cr}(\mathrm{mg} / \mathrm{kg})$ in fractions of sediments of Lake Skadar:

\begin{tabular}{ccccc}
\hline Fractions & I & II & III & IV \\
\hline Min.-max. & $0-1.28$ & $0.10-3.06$ & $11.8-91.4$ & $15.4-57.4$ \\
Mean value & 0.24 & 1.14 & 35.2 & 31.9 \\
\hline
\end{tabular}

I - Removable and easy mobile; II - Reductable; III - Oxidable; IV - Residual

The highest amount of $\mathrm{Cr}$ is in the oxidable (organic) fraction, at a percent by weight of $50.6 \%$, relative to the total content. Chromium follows the following trend of distribution by fractions: III > IV > II > I. In the changeable, easy soluble fraction there is an inconsiderable amount of $\mathrm{Cr}(0.35 \%)$ and this might be considered immobilized metal.

Table 3 shows the mean values of the total and extractable $\mathrm{Cr}$ content (minimum and maximum values and mean values) in the sediment for five different extraction mechanisms:

Table 3. Concentration of $\mathrm{Cr}(\mathrm{mg} / \mathrm{kg})$ extracted by various solvents

\begin{tabular}{|c|c|c|c|c|c|c|}
\hline & Total $\mathbf{C r}$ & $\begin{array}{l}0.1 \mathrm{M} \\
\mathrm{NH}_{4} \mathrm{Cl} \\
(\mathrm{pH} \mathrm{9})\end{array}$ & $\begin{array}{l}0.1 \mathrm{M} \\
\mathrm{CaCl}_{2} \\
(\mathrm{pH} 7)\end{array}$ & $\begin{array}{c}\text { 0.1 M } \\
\mathrm{CH}_{3} \mathrm{COONa} \\
(\mathrm{pH} \mathrm{9)}\end{array}$ & $\begin{array}{c}\mathbf{0 . 1 M} \\
\mathrm{H}_{2} \mathrm{C}_{2} \mathrm{O}_{4} \\
(\mathrm{pH} 2)\end{array}$ & $\begin{array}{l}\text { 0.1 M } \\
\text { EDTA } \\
\text { (pH 7) }\end{array}$ \\
\hline Min.-max. & $35.6-127$ & $0.02-0.22$ & nd & $0-0.20$ & $2.98-16.4$ & $0.29-3.36$ \\
\hline Mean value & 68.4 & 0.08 & & 0.08 & 7.91 & 1.20 \\
\hline
\end{tabular}


The order of solvents with a descending share of extracted $\mathrm{Cr}$, compared to the total content, was as follows: $\mathrm{H}_{2} \mathrm{C}_{2} \mathrm{O}_{4}(11.6 \%)>$ EDTA $(1.75 \%)>\mathrm{NH}_{4} \mathrm{Cl}(0.11 \%), \mathrm{CH}_{3} \mathrm{COONa}$ $(0.11 \%)>\mathrm{CaCl}_{2}(0 \%)$.

Acidic conditions $\left(0.1 \mathrm{M} \mathrm{H}_{2} \mathrm{C}_{2} \mathrm{O}_{4}, \mathrm{pH}=2\right)$ have shown a higher potential for the extraction of $\mathrm{Cr}$. Chromium showed a 6.6 times higher rate of extractability in oxalic acids than in EDTA. The generation of the Cr (III) complex of EDTA at room temperature is very slow, in spite of its high stability constant $(\mathrm{pKa}=23)$.

The results of the metal content in individual parts of the examined macrophytes across the seasons are given in Table 4:

Table 4. Seasonal changes in concentrations of $\mathrm{Cr}(\mathrm{mg} / \mathrm{kg}$ of dry matter) in parts of investigated plants; minimum and maximum value and the mean value of concentration \pm standard deviation

\begin{tabular}{|c|c|c|c|c|c|}
\hline \multirow[b]{2}{*}{ Plant } & \multirow{2}{*}{$\begin{array}{l}\text { Part of } \\
\text { plant }\end{array}$} & \multicolumn{4}{|c|}{$\begin{array}{c}\text { Min.-max. } \\
\text { Mean value } \pm \text { S.D. }\end{array}$} \\
\hline & & April & June & August & October \\
\hline \multirow{3}{*}{ P. australis } & root & $\begin{array}{c}1.25-4.73 \\
3.32 \pm 1.21 \mathbf{a}^{*}\end{array}$ & $\begin{array}{c}3.27-19.1 \\
10.3 \pm 6.31 \mathbf{a}\end{array}$ & $\begin{array}{c}4.00-12.4 \\
7.98 \pm 2.80 \mathbf{a}\end{array}$ & $\begin{array}{c}2.37-10.7 \\
5.90 \pm 2.32 \mathbf{a}\end{array}$ \\
\hline & stem & $\begin{array}{c}0.49-1.77 \\
1.05 \pm 0.52 \mathbf{b}\end{array}$ & $\begin{array}{c}1.28-6.16 \\
2.68 \pm 1.76 \mathbf{b}\end{array}$ & $\begin{array}{c}0.80-3.75 \\
2.09 \pm 1.22 \mathbf{b}\end{array}$ & $\begin{array}{c}0.40-3.20 \\
1.26 \pm 1.03 \mathbf{b}\end{array}$ \\
\hline & leaf & $\begin{array}{c}0.21-0.38 \\
0.28 \pm 0.06 \mathbf{b}\end{array}$ & $\begin{array}{c}0.28-0.88 \\
0.48 \pm 0.22 \mathbf{b}\end{array}$ & $\begin{array}{c}0.41-1.09 \\
0.66 \pm 0.24 \mathbf{b}\end{array}$ & $\begin{array}{c}0.70-1.99 \\
1.24 \pm 0.43 \mathbf{b}\end{array}$ \\
\hline \multirow{2}{*}{ C. demersum } & stem & $\begin{array}{c}3.55-8.81 \\
6.32 \pm 1.85 \mathbf{b}\end{array}$ & $\begin{array}{c}1.49-4.43 \\
3.21 \pm 1.32 \text { bcd }\end{array}$ & $\begin{array}{c}1.00-2.86 \\
2.12 \pm 0.78 \text { cd }\end{array}$ & $\begin{array}{c}0.89-2.98 \\
1.61 \pm 0.74 \mathbf{~ d}\end{array}$ \\
\hline & leaf & $\begin{array}{c}4.27-18.6 \\
11.4 \pm 4.97 \mathbf{a}\end{array}$ & $\begin{array}{c}3.14-9.00 \\
5.78 \pm 2.07 \text { bc }\end{array}$ & $\begin{array}{c}2.29-8.19 \\
4.62 \pm 2.09 \text { bcd }\end{array}$ & $\begin{array}{c}2.08-7.28 \\
3.92 \pm 1.88 \text { bcd }\end{array}$ \\
\hline \multirow{2}{*}{ L. minor } & root & & & $\begin{array}{l}0.79-3.08 \\
1.60 \pm 1.01 \\
\end{array}$ & $\begin{array}{l}2.18-4.58 \\
3.31 \pm 1.04 \\
\end{array}$ \\
\hline & leaf & & & $\begin{array}{l}1.18-1.78 \\
1.36 \pm 0.28\end{array}$ & $\begin{array}{l}1.57-5.32 \\
2.81 \pm 1.73\end{array}$ \\
\hline
\end{tabular}

* Means indicated by different letters within each row are significantly different at $p<0.05$.

Figure 2 presents the average seasonal changes in the bioconcentration factor $(\mathrm{BCF})$ of the examined macrophytes for $\mathrm{Cr}$.

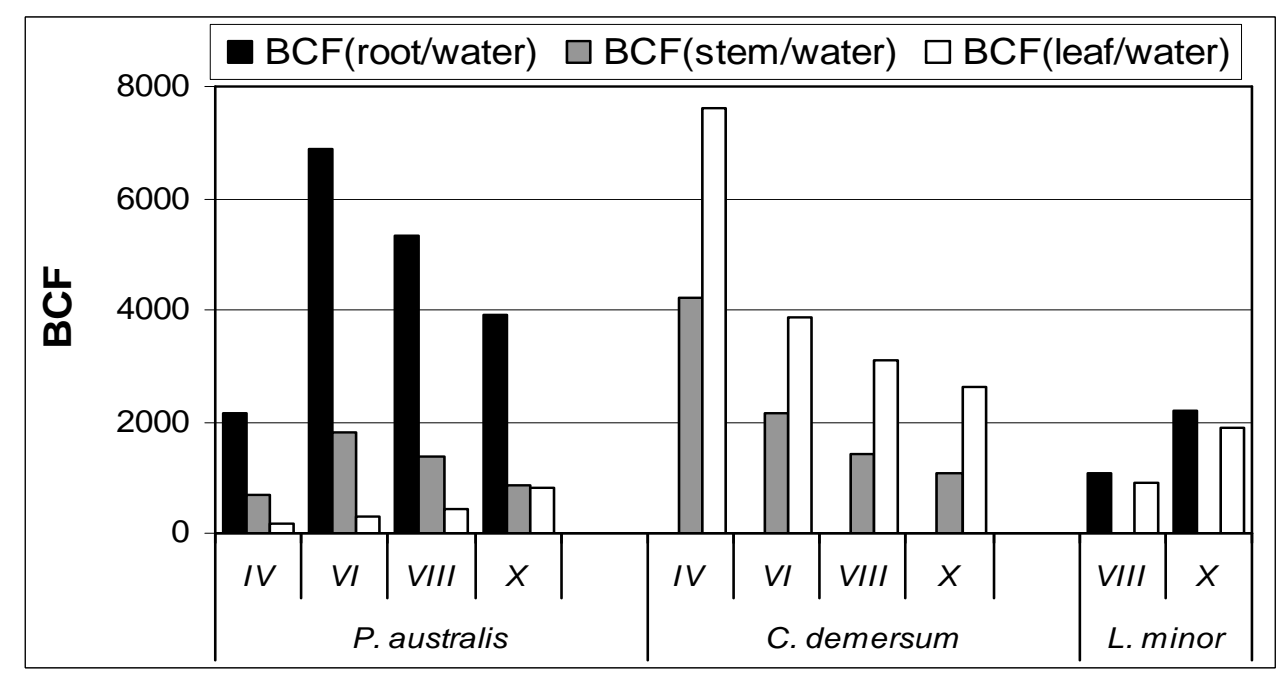

Figure 2. Seasonal changes in bioconcentration factors $(\mathrm{BCF})$ for $\mathrm{Cr}$ in the examined macrophytes 
Regardless of the sampling period, $\mathrm{Cr}$ in the parts of $P$. australis follows the trend of concentration: root $>$ stem $>$ leaf.

The concentrations of $\mathrm{Cr}$ in some parts of $C$. demersum differ significantly from their concentrations in the water and sediment, and follow the trend: sediment $>C$. demersum leaf $>$ C. demersum stem $>$ water. A higher content of $\mathrm{Cr}$ is recorded in the leaf of $C$. demersum at all locations and in all seasons. It is noteworthy that in submerged macrophytes translocation is not definitive, since in addition to the translocation from the stem, the leaf contains metals absorbed from water.

The concentration of $\mathrm{Cr}$ in some parts of $L$. minor decreases in the following order: sediment $>L$. minor $_{\text {root }}>L$. minor $_{\text {leaf }}>$ water. The highest amount of $\mathrm{Cr}$ was found in the root sampled from the right bank of the mouth of the Morača River and in the leaf from the left bank of the mouth of the Morača River. Looking at the seasons, almost twice as much content is recorded in October than in August, in both the root and the leaf. Higher values for the leaf and root were recorded in October than in August. The average seasonal values of metal are higher in the root than in the leaf.

Values for the translocation ability of $\mathrm{Cr}$ are shown in Table 5:

Table 5. Seasonal changes in the translocation ability (TA) of macrophytes tested for $\mathrm{Cr}$

\begin{tabular}{llcccc}
\hline Macrophytes & & April & June & August & October \\
\hline \multirow{3}{*}{ P. australis } & stem/root & 0.24 & 0.22 & 0.19 & 0.16 \\
\cline { 2 - 6 } & leaf/root & 0.08 & 0.04 & 0.08 & 0.19 \\
\cline { 2 - 6 } & leaf/stem & 0.34 & 0.18 & 0.41 & 1.19 \\
\hline C. demersum & leaf/stem & 1.52 & 1.78 & 1.97 & 2.27 \\
\hline L. minor & leaf/root & & & 0.81 & 0.68 \\
\hline
\end{tabular}

\section{Chromium distribution in sediment}

Chromium had an average content of $68.4 \mathrm{mg} / \mathrm{kg}$ of dry sediment at the six studied locations around Lake Skadar, and is in the range of 35.6 to $127 \mathrm{mg} / \mathrm{kg}$ (Table 1). The highest concentration was observed in the sediments taken from the site at Plavnica. Chromium content in the easily available fraction either was not recorded or an insignificant amount of bioavailable $\mathrm{Cr}$ was recorded in all locations. According to PETROvić (1981), high concentrations of $\mathrm{Cr}$ in the sediment are of geological origin and are not related to anthropogenic pollution. The largest amount of $\mathrm{Cr}$ in the sediments of Lake Skadar was in the residual fraction (51.3\%) (Figure 2) followed by the oxidized fraction (46.7\%), as a result of the stronger adsorption ability of $\mathrm{Cr}$ into organic matter than the $\mathrm{Fe}$ and $\mathrm{Mn}$-oxyhidroxides. The content of $\mathrm{Cr}$ in fraction I is very low, only $0.7 \%$ of its total content, which reduced its potential toxicity as a pollutant in Lake Skadar.

DAVIDSON et al. (1998) found the highest content of $\mathrm{Cr}$ in the residual fraction. Additionally, FERNANDEZ et al., (11) recorded the highest concentration of $\mathrm{Cr}$ in the fourth fraction with a lower content of oxidized material and found that it was significantly lower in the reducible fraction of the sediment.

\section{Bioaccumulation of $\mathrm{Cr}$ in macrophytes}

\section{Phragmites australis (Cav.) Trin. ex Steud}

The results of this study show that most of Cr taken up by plants, was found in the roots (Table 4). The highest root and stem accumulation was recorded in June, and then the rate decreased. Chromium concentration in the leaves of $P$. australis increased slightly during the entire investigation period.

BRAGATO et al. (2009) examined the accumulation of four metals $(\mathrm{Cu}, \mathrm{Zn}, \mathrm{Ni}$ and $\mathrm{Cr}$ ) in $P$. australis in experimentally constructed wetlands which receive water from the River Po 
in Italy. Chromium was found to be accumulated in the stems and rhizome of $P$. australis mostly in July, and then the amount decreased and became constant from August to December.

In addition to lower accumulation, $\mathrm{Cr}$ also showed low mobility. In this study, the average ratio of accumulation in the root/aboveground part ranged from 4.10 (April) to 25.8 (June). During the growing season, the translocation ratio decreased indicating the limited transportation of toxic metals from roots to shoots. Some authors (KÄHKÖNEN et al., 1997; BALDANTONI et al., 2004; VYMAZAL et al., 2007) indicate a low mobility of Cr from roots to shoots and leaves. It is obvious that there is a physiological barrier, i.e. the absence of a transport mechanism for this element from roots to the green parts of the plant. The relatively low concentration of $\mathrm{Cr}$ in foliar tissues during the whole sampling period is probably the result of the plant needing to prevent the pollution of the photosynthetic apparatus, as suggested by other authors (LANDBERG and GREGER, 1996; STOLTZ and GREGER, 2002; BRAGATO et al., 2006).

\section{Ceratophyllum demersum $\mathrm{L}$.}

Significant seasonal variations in concentrations of $\mathrm{Cr}$ have been observed (Table 4). The highest concentrations were recorded in the stem and in the leaf during April, which then decreased until October. Chromium content ranged from 0.89 to $8.81 \mathrm{mg} / \mathrm{kg}$ (average 3.32 $\mathrm{mg} / \mathrm{kg}$ ) in the stems while in the leaves it ranged from 2.08 to $18.6 \mathrm{mg} / \mathrm{kg}$ (average 6.44 ). The bio-concentration degree of $\mathrm{Cr}$ in relation to the sediment in $C$. demersum is low. However, there is a noticeable translocation within the plant, with an average ratio leaf/stem of 1.85 (Table 5), depending on locations and sampling periods.

The results of RAI et al. (1995) have showed that $C$. demersum, under laboratory conditions, reduces the level of $\mathrm{Cr}$ in water contaminated by effluents from various industrial sources. Reduction varies from a concentration of $4.866 \mu \mathrm{M}$ to below $2 \mu \mathrm{M}$. Their results indicated the possibility of removing $\mathrm{Cr}$ from diluted waste water using this plant. Higher concentrations of $\mathrm{Cr}$ in the leaves $(1.03-2.71 \mathrm{mg} / \mathrm{kg})$ compared to the stems of $C$. demersum were found by POURKHABBAZ et al. (2011). In the paper written by OsMOLOVSKAYA and KURYLENKO (2005) the $\mathrm{Cr}$ content was 16.5 times higher in the tissues of $C$. demersum originating from polluted lake ecosystems when compared to unpolluted ones.

\section{Lemna minor $\mathbf{L}$.}

Chromium has a low content in the parts of L. minor. The mean value of $\mathrm{Cr}$ during the research period in the root was $2.46 \mathrm{mg} / \mathrm{kg}$, while in the leaf it is $2.09 \mathrm{mg} / \mathrm{kg}$. The content of $\mathrm{Cr}$ in the leaf in October $(5.32 \mathrm{mg} / \mathrm{kg})$ significantly stands out from the other results for $\mathrm{Cr}$. Higher values of $\mathrm{Cr}$ in the roots and in the leaves were recorded in October than in August. The bioaccumulation capacity of L. minor for $\mathrm{Cr}$ was higher in the roots comparing to the leaves. The bioaccumulation ability of $L$. minor for $\mathrm{Cr}$ is moderate as has been demonstrated by other authors (ZAYED, 1998). ATER et al., (2006) observed the effectiveness of L. minor in the phytoremediation of $\mathrm{Cr}$, especially for lower levels of contamination of the aquatic environment.

\section{Correlation analysis of $\mathrm{Cr}$ in macrophytes and the sediment}

Table 6 shows the values of Pearson's correlation coefficients (r) between the content of $\mathrm{Cr}$ in the surrounding environment (the sediment) and various parts of the macrophytes.

On the basis of the presented results, the following macrophytes of their individual parts can be proposed as bioindicators to assess the $\mathrm{Cr}$ load of the surrounding environment (sediment): P. australis (the stem), C. demersum (the stem and the leaf at the beginning and end of the growing season) and L. minor (the root and the leaf at the end of the growing season). 
Table 6. Correlation coefficients, between the sediment and certain parts of the macrophytes

\begin{tabular}{|c|c|c|c|c|c|c|c|c|c|}
\hline \multirow[t]{2}{*}{ Metal } & & \multirow[t]{2}{*}{ Month } & \multicolumn{3}{|c|}{ P. australis } & \multicolumn{2}{|c|}{ C. demersum } & \multicolumn{2}{|c|}{ L. minor } \\
\hline & & & root & stem & leaf & stem & leaf & root & leaf \\
\hline \multirow{4}{*}{$\mathrm{Cr}$} & \multirow{4}{*}{ Sediment } & IV & 0.45 & -0.36 & 0.65 & 0.65 & 0.58 & & \\
\hline & & VI & 0.81 & 0.79 & -0.19 & 0.31 & 0.30 & & \\
\hline & & VIII & -0.20 & 0.81 & -0.25 & 0.33 & 0.91 & -0.03 & -0.15 \\
\hline & & $\mathbf{X}$ & -0.13 & 0.85 & -0.79 & 0.99 & 0.88 & 0.51 & 0.91 \\
\hline
\end{tabular}

$\mathrm{p} \leq 0.05$

Most of previous studies have shown insignificant correlation between the concentration of metals absorbed by macrophytes and concentrations in sediments (NOURI et al., 2009). KELLER et al. (1998) consider that the absorption of the metal, either by roots or leaves, is not in linear correlation with increasing metal content in the surrounding environment. The lack of correlations, in most cases, indicate that these relationships do not dominate in determining the metal content adopted by the plant. The accumulation of metals in the tissues of macrophytes, in addition to their content in the sediment, depends on the interaction and variation of many other factors.

In contrary to this paper, SZYMANOWSKA et al. (1999) found a high positive correlation between the concentration of $\mathrm{Cr}$ in $P$. australis and $C$. demersum and the surrounding sediments. Unlike the tests in this paper, BRAGATO et al. (2006) found that the concentration of $\mathrm{Cr}$ in the incoming water and in the sediment was not correlated with the content in P. australis.

\section{CONCLUSIONS}

Chromium is an immobilized metal, because the greater of its part is incorporated the crystal lattice of minerals (residual fraction). A small amount of this metal (as seen in relation to the total content) is in the removable, easy soluble fraction.

Bioavailable amounts of $\mathrm{Cr}$ originate from the exchangeable and smaller part of the organic fraction of the sediments.

Chromium concentrations in plant tissues depended on sampling season. In $P$. australis concentrations decreased from June to the end of the growing season, while in $L$. minor they increase from August to October. The highest $\mathrm{Cr}$ content during the tested season was determined in the leaves of $C$. demersum in April $(11.4 \mathrm{mg} / \mathrm{kg})$, and the lowest was in the same month in the leaves of $P$. australis. The highest average concentration of $\mathrm{Cr}$ for the tested season was in the root of $P$. australis. The amount of accumulated $\mathrm{Cr}$ decreased on average during the season within the plants in the following order: $C$. demersum $>P$. australis $>$ L. minor.

The average value of the bioaccumulation factor calculated for the entire plant was identical for $P$. australis and $C$. demersum, whereas in L. minor the value was significantly less.

\section{References}

[1] Agbaba, J., Dalmacija, B., Maletić, S., RonČević, S., Božović, Lj. (2008): Neorganske komponente u sistemu voda-sediment. U: DALMACIJA, B. i AGBABA, J. (ur.) Zagađujuće materije u vodenom ekosistemu $i$ remedijacioni procesi, Departman za hemiju PMF, Novi Sad, p. 183-262 
[2] Ater, M., Ali, N.A., KASMi, H. (2006): Tolerance and accumulation of copper and chromium in two duckweed species: Lemna minor L. and Lemna gibba L. Journal of Water Science 19: 57-67

[3] Babović, N., Dražıć, G., Duordjević, A., Mihailović, N. (2010): Heavy and toxic metal accumulation in six macrophythe species from fish pond Ečka, Republic of Serbia. BALWOIS Conference, Ohrid, Republic of Macedonia, 25-29 May 2010

[4] Baldantoni, D.A., Alfani, A., Tommasi, P.D., Bartoli, G., Santo, A.V., (2004): Assessment of macro and microelement accumulation capability of two aquatic plants. Environmental Pollution 130: 149-156.

[5] Bowen, H.J.M. (1979): Environmental chemistry of the elements, Academic Press, London.

[6] Bragato, C., Brix, H., Malagoli, M. (2006): Accumulation of nutrients and heavy metals in Phragmites australis (Cav.) Trin. ex Steudel and Bolboschoenus maritimus (L.) Palla in a constructed wetland of the Venice lagoon watershed. Environmental Pollution 144: 967-975

[7] Bragato, C., Schiavon, M., Polese, R., Ertani, A., Pittarello, M.M., Malagoli, M. (2009): Seasonal variations of $\mathrm{Cu}, \mathrm{Zn}, \mathrm{Ni}$ and $\mathrm{Cr}$ concentration in Phragmites australis (Cav.) Trin.ex Steud. In a constructed wetland of North Italy. Desalination 247: $36-45$.

[8] Choudhury, S., Panda, S.K. (2005): Toxic effects, oxidative stress and ultrastructural changes in moss Taxithelium nepalense (Schwaegr.) Broth. under chromium and lead phytotoxicity. Water Air and Soil Pollution 167: 73-90.

[9] Davidson, C.M., Duncan, A.L., LitTeljohn, D., Ure, A.M., Garden, L.M. (1998): A critical evaluation of the three stage BCR sequential extraction procedure to assess the potential mobility and toxicity of heavy metals in industrially-contaminated land. Analytica Chimica Acta 363: 45-55.

[10] Deng, H., YE, Z.H., Wong, M.H. (2004): Accumulation of lead, zinc, copper and cadmium by 12 wetland plant species thriving in metal-contaminated sites in China. Environmental Pollution 132: 29-40.

[11] Fernandez, E., Jimenez, R., Lallena, A.M., Aguilar, J. (2004): Evaluation of the BCR sequential extraction procedure applied for two unpolluted Spanish soils. Environmental Pollution 131: 355-364.

[12] HAWKer, D., ConNell, D. (1991): An evaluation between bioconcentration factor and aqueous solubility. Chemosphere 23: 231-241.

[13] Kabata-Pendias, A., Pendias. H. (1992): (Eds.), Trace Elements in Soils and Plants, CRC Press, Baton Rouge, USA.

[14] KähKönen, M.A., Souminen, K.P., Manninen, P.K.G., Salkinoja-Salonenm, MS. (1997): Sediment deposition of organic halogens and heavy metals in pristine forest lakes and pulp mill recipient area. Proceedings of the Third Finnish Conference on Environmental Science. pp.179-183.

[15] KAStORI, R., MAKSIMOVIĆ, I. (2006): Fitoremedijacija teških metala biološke osnove. Seminar: Zaštita životne sredine remedijacija, Beograd. Privredna komora Srbije. Zbornik radova.

[16] Keller, B., Lajtha, K., Cristofor, S. (1998): Trace metal concentrations in the sediments and plants of the Danube delta, Romania. Wetlands 18: 42-50.

[17] KovÀcs, M., NyARY, I., ToTH, L. (1984): The microelement content of some submerged and floating aquatic plants. Acta Botanica Academiae Scientiarum Hungaricae 30: 173185.

[18] LAndBerg, T., Greger, M. (1996): Differences in uptake and tolerance to heavy metal in Salix from unpolluted and polluted areas. Applied Geochemistry 11: 175-180. 
[19] Nouri, J., Khorasani, N., Lorestani, B., Karami, M., Hassani, A.H., Yousefi, N. (2009): Accumulation of heavy metals in soil and uptake by plant species with phytoremediation potential. Environmental Earth Sciences 59: 315-323

[20] OliveIRA, H. (2012): Chromium as an environmental pollutant: Insights o induced plant toxicity. Journal of Botany, Article ID 375843, 8 pages, DOI:10.1155/2012/375843

[21] Osmolovskaya, N., KuRILENKO, V. (2005): Macrophytes in phytoremediation of heavy metal contaminated water and sediments in urban inland ponds. Geophysical Research Abstracts 7: 10510.

[22] Outridge, P., Noller, B. (1991): Accumulation of toxic trace elements by freshwater vascular plants. Reviews of Environmental Contamination and Toxicology 121: 2-63.

[23] Paiva, L.B., DE Oliveira, J.G., AzeVEdo, R.A., Ribeiro, D.R., DA Silva, M.G., VitóRiA, A.P. (2009): Ecophysiological responses of water hyacinth exposed to $\mathrm{Cr}^{3+}$ and $\mathrm{Cr}^{6+}$. Environmental and Experimental Botany 65: 403-409.

[24] Peralta-Videa, J.R., Lopez, M.L., Narayan, M., Saupe, G., Gardea-Torresdey, J. (2009): The biochemistry of environmental heavy metal uptake by plants: implications for the food chain. International Journal of Biochemistry and Cell Biology 41: 16651677.

[25] Petrović, G. (1981): Chemichal investigations of water and sediments of Lake Skadar, The Biota and Limnology of Lake Skadar. University of Michigan, Ann Arbor Michigan, U.S.A., pp 68-93.

[26] Pourkhabbaz, A.R., Pourkhabbaz. H.R., Khazaei, T., Behravesh, S., EBRAHIMPOUR, M. (2011): Assessment of heavy metal accumulation in Anzali wetland, Iran, using a submerged aquatic plant, Ceratophyllum demersum. African Journal of Aquatic Science 36: 261-265.

[27] Pueyo, M., Sastre, J., Hernandez, E., Vidal, M., Lopez-Sanchez, J.F., Rauret, G. (2003): Prediction of trace element mobility in contaminated soils by sequential extraction. Journal of Environmental Quality 2: 2054-2066.

[28] Rai, U.N., Sinha, S., TRIPATHI, R.D., ChandRA, P. (1995): Wastewater treat ability potential of some aquatic macrophytes: Removal of heavy metals. Ecological Engineering 5: 5-12.

[29] Schiavon, M., Pilon-Smits, E., Wirtz, M., R. Hell, R., M. Malagoli, M. (2008): Interactions between Chromium and Sulfur Metabolism in Brassica juncea. Journal Environmental Quality 37: 1536-1545.

[30] Stoltz, E., Greger, M. (2002): Accumulation properties of $\mathrm{As}, \mathrm{Cd}, \mathrm{Cu}, \mathrm{Pb}$ and $\mathrm{Zn}$ by four wetland plant species growing on submerged mine tailings. Environmental and Experimental Botany 47: 271-280.

[31] Szymanowska, A., SAmeCKA-Cymerman, A., Kempers, A.J. (1999): Heavy metals in three lakes in West Poland. Ecotoxicology Environmental Safety 43: 21-29.

[32] Tremp, H., Kohler, A. (1995): The usefulness of macrophyte monitoring systems, exemplified on eutrophication and acidification of running waters. Acta Botanica Gallica 142: 541-550.

[33] USEPA Method 3051a. (2007): Microwave assisted acid digestion of sediments, sludges, soils and oils, Revision 1.

[34] Veselinović, D., GRŽEtić, I., ĐARMati, Š., Marković, D. (1995): Fizičkohemijski osnovi zaštite životne sredine, stanja i procesi u životnoj sredini, Fakultet za fizičku hemiju Univerziteta u Beogradu.

[35] Vymazal, J., Švehla, J., KröPfelová, L., Chrastný, V. (2007): Trace metals in Phragmites australis and Phalaris arundinacea growing in constructed and natural wetlands. Science of the Total Environment 380: 154-162.

[36] ZAYED, A. (1998): Phytoaccumulation of trace elements by wetland plants Duckweed. Journal of Environmental Quality 27: 715-721. 